\title{
Ile jest kryminału w kryminale? O samoświadomości gatunku na przykładzie Kamiennej nocy Gai Grzegorzewskiej
}

\author{
Klaudia Pilarska
}

Współczesna polska powieść kryminalna jest zagadnieniem wielce interesującym, ale i niebywale kłopotliwym. Trudno bowiem mówić o polskiej szkole kryminału - tak jak to ma miejsce w przypadku powieści skandynawskich - czy też wyszczególnić wspólny rys dla polskich twórców. Niemniej jednak, najwięcej o specyfice powstających w naszym kraju powieści kryminalnych można powiedzieć na podstawie tych utworów, które, choć powstały w konwencji klasycznego kryminału, najbardziej od niego odbiegają. Jednak, aby te odstępstwa ukazać, należy wskazać pewne charakterystyczne dla gatunku prawidłowości. Jak zauważa Ryszard Handke:

\begin{abstract}
Jednym z czynników kuszących badacza literatury do zajęcia się literaturą popularną - choć zarazem być może zniechęcającym - jest przejawianie się w niej różnego typu prawidłowości. O ile bowiem arcydzieło jest z natury swej zjawiskiem w jakiś sposób niepowtarzalnym, nie dającym się sprowadzić do poziomu żadnych innych utworów, gdyż je przerasta [...], o tyle dzieła należące do literatury popularnej stanowią doskonały teren do zaobserwowania elementów występujących wielokrotnie, schematów postaci, wędrownych motywów, matryc fabularnych. Powtarzalność ta sprawia przy tym, że o ile arcydzieło jest zawsze imiennie związane $z$ autorem [...], o tyle w literaturze popularnej - zwłaszcza dla jej przeciętnego odbiorcy - ważna staje się sama jej odmiana (kryminał, western czy romans), [...]. Owa powtarzalność może oczywiście badacza zniechęcić - nieciekawa bowiem w analitycznym postępowaniu staje się literatura nie nosząca w sobie piętna indywidualnej ludzkiej osobowości, gatunek, z którego wystarczy przeczytać kilka utworów, by w następnych odnaleźć zjawiska i problemy niemal identyczne. Z drugiej strony jednak stwarza ona także pewne możliwości - pozwala na formułowanie uogólnień w głównej mierze odnoszących się do tej literatury, ale przecież nie wyłącznie do niej ${ }^{1}$.
\end{abstract}

Intertekstualność jest nieodłącznym elementem współczesnego kryminału - także polskiego. Dlatego też zdecydowałam przyjrzeć się Kamiennej nocy Gai Grzegorzewskiej, dla której interteks-

\footnotetext{
${ }^{1}$ R. Handke, Fabularność współczesnych form narracyjnych, [w:] Studia o narracji powieści popularnej, red. J. Błoński, J. Jaworski, J. Sławiński, Wrocław 1982, s. 14-15.
} 
tualność stanowi ważny punkt odniesienia. Wszystkie nawiązania gatunkowe i (pop)kulturowe mają znaczenie, gdyż dotyczą kreacji bohaterów, którzy wraz z nietypowo poprowadzoną narracją, stanowią w polskim kryminale swego rodzaju ewenement. Powieść Grzegorzewskiej odznacza się również dużą dozą brutalności i przemocy, co biorąc pod uwagę, że jest to kryminał pisany przez kobietę - a takie powieści właśnie mnie interesują - wydaje się jeszcze bardziej niekonwencjonalne.

Kamienna noc Gai Grzegorzewskiej to powieść wyróżniająca się na tle kryminalnych półproduktów zalewających rynek wydawniczy. Chociaż książka ta jest osadzona w gatunkowych ramach kryminału, gra z jego konwencją i wychodzi poza utarte schematy. Sama autorka przeszła długą drogę, by w najnowszej powieści odrzucić kryminalne konwenanse i wywrócić na nice zakorzeniony we własnej tradycji gatunek.

Drogę tę zaczęła Grzegorzewska od książki Żniwiarz (2006), która zapoczątkowała cykl powieści kryminalnych z detektyw Julią Dobrowolską. Postać Dobrowolskiej stanowi ważne ogniwo łączące tę serię z trylogią kryminalną z Profesorem, odgrywającym kluczową rolę w $\mathrm{Ka}$ miennej nocy². Kolejno ukazały się Noc z czwartku na niedzielę (2007), Topielica (2010) i Grób (2012). Cykl ten odzwierciedla stopniowe odejście Grzegorzewskiej od tradycji kryminalnej ku bardziej eksperymentalnej formie, którą autorka zaprezentowała w Kamiennej nocy.

W początkowych powieściach Grzegorzewskiej wyraźnie widać odwołania do twórczości Agathy Christie i wykorzystanie mechanizmów charakterystycznych dla większości jej powieści. Te gatunkowe prawidłowości - w cyklu z Julią Dobrowolską - uwidaczniają się właśnie na płaszczyźnie fabularnej i konstrukcyjnej. Żniwiarz jest skomponowany na wzór najbardziej poczytnych książek królowej kryminału, jak Tajemnicza historia w Styles, Niedziela na wsi czy Morderstwo na plebani ${ }^{3}$. Grzegorzewska wykorzystuje konstrukcję powieści kominkowej, gdzie na końcu detektyw przedstawia rozwiązanie zagadki. W podobny sposób co Christie tworzy także atmosferę powieści, wykorzystując takie fabularne elementy, jak: wieś, małą skrywającą liczne tajemnice społeczność, morderstwo i pozbywanie się kolejnych istotnych świadków zbrodni ${ }^{4}$. W Topielicy zaś Grzegorzewska umieszcza zwłoki dopiero w połowie książki, co również jest chwytem zapożyczonym od angielskiej pisarki, a sama fabuła pod względem scenerii przypomina Śmierć na Nilu. Jednakże największy zwrot można zauważyć w czwartej powieści zatytułowanej Grób. Inspiracje twórczością Agathy Christie Grzegorzewska porzuca na rzecz atmosfery grozy rodem z powieści gotyckiej i popkulturowego fenomenu, jakim okazał się serial The Walking dead ${ }^{5}$. Żadna z dotychczasowych powieści Grzegorzewskiej nie wprowadziła jednak tyle zamętu co Kamienna noc.

\footnotetext{
${ }^{2}$ Mowa o Betonowym pałacu (2014) i Kamiennej nocy (2016), których bohaterem-narratorem w głównej mierze autorka uczyniła Profesora - postać pojawiającą się w Grobie, czwartej części cyklu z Julią Dobrowolską. Data wydania trzeciej wieńczącej trylogię książki nie jest obecnie znana.

3 Tytuły rozdziałów w Żniwiarzu są jednocześnie tytułami powieści Agathy Christie, m.in: Dom nad kanałem, Karty na stół czy Morderstwo na plebani. Żniwiarz jest wręcz naszpikowany kryptocytatami odnoszącymi się do twórczości Christie (choć pojawiają się też nawiązania popkulturowe, jak słynna scena pod prysznicem z Psychozy Hitchcocka), toteż można go postrzegać jako rodzaj hołdu dla angielskiej pisarki.

${ }^{4}$ Agatha Christie była zdania, że „nic tak nie ożywia powieści kryminalnej jak kolejny trup”. Gaja Grzegorzewska zdaje się wychodzić z tego samego założenia, gdyż - podobnie jak Christie - uśmierca świadków na chwilę przed tym, nim zdradzą informacje dotyczące tożsamości mordercy.

${ }^{5}$ Amerykański serial telewizyjny będący adaptacją komiksu o tym samym tytule, który opowiada o postapokaliptycznym świecie opanowanym przez zombie. W Polsce znany pod tytułem Żywe trupy. Grzegorzewska nawiązuje do serialu, opierając zagadkę kryminalną na znikaniu zwłok i nekrofilii, a także poprzez bezpośrednie użycie w tekście terminu „żywe trupy”.
} 
W tej powieści autorka do tego stopnia naruszyła konwencje kryminału, że wśród niezadowolonych czytelników pojawiły się głosy, że kryminałem nie jest. Wydaje się więc, że Grzegorzewska zdecydowanie woli poszukiwać nowych środków wyrazu, niż odpowiadać czytelniczym oczekiwaniom, bawi się formą, do konwencji powieści kryminalnej podchodzi nader plastycznie, nie zapomina jednak, z jakim gatunkiem ma do czynienia.

Powieść kryminalna nie może obyć się bez kryminalnej zagadki (najczęściej morderstwa), intrygi mającej na celu zatuszowanie zbrodni oraz śledztwa i postaci detektywa, którego celem jest rozwikłanie owych elementów. Pod tym względem Kamienna noc spełnia wszystkie wymagane kryteria. Znana z wcześniejszych powieści Julia Dobrowolska, prywatna detektyw, prowadzi śledztwo w sprawie gwałtu i zabójstwa kilkuletniej Helenki Karo. Przy okazji Julia próbuje odpowiedzieć na pytanie, czy matka dziewczynki rzeczywiście popełniła samobójstwo. Śledztwo osadzone jest więc na schemacie podwójnej zagadki, którą upodobała sobie większość autorów powieści kryminalnych i która uchodzi za jeden ze sztandarowych chwytów w tym gatunku. Oczywiście, jak przystało na dobry kryminał, wątek dochodzenia nie jest jedynym, który tworzy płaszczyznę fabularną.

Równie istotne są sprawy prywatne i sama postać detektywa. Także w przypadku Kamiennej nocy główna bohaterka, czy raczej bohaterowie - Julia i Profesor, została skonstruowana wedle podobnego, charakterystycznego dla powieści kryminalnej, schematu. Bohater kryminału musi mieć jakąś szczególną cechę, jakiś charakterystyczny rys, który zapadnie w pamięć czytelnikowi. Najczęściej są to: uzależnienie (zazwyczaj alkoholowe), problemy osobiste (rozwód) bądź trudności w nawiązywaniu relacji (wszystkie związki i więzi ulegają rozpadowi z powodu pracy). W tym względzie ani Julia, ani Profesor nie stanowią wyjątku. Julia nie stroni od alkoholu, pali nałogowo i często zmienia partnerów, by nie rzec kolokwialnie, że sypia z kim popadnie. Do tego wyróżnia ją znacznej wielkości szrama na policzku, która początkowo pozostaje dla czytelnika tajemnicą ${ }^{6}$. Nie inaczej rzecz się ma z drugim protagonistą Kamiennej nocy. Łukasz - znany bardziej jako Profesor - należy do szemranego krakowskiego półświatka i jak się okazuje, jest nie tylko starym znajomym Julii, ale i jej przyrodnim bratem. Właśnie na kazirodczym związku tych dwojga Grzegorzewska opiera fabułę Kamiennej nocy. To interesujące rozwiązanie, bo motyw kazirodztwa nie jest zbyt często wykorzystywany w powieściach kryminalnych (a już na pewno nie w polskiej odmianie). Związek między Julią a Profesorem rodzi problemy nie tylko natury prawnej (kazirodztwo jest przestępstwem ściganym z paragrafu 201), ale i emocjonalnej. Mimo tego, że bohaterowie są świadomi niestosowności swojej relacji, a także mimo ciążącego na nich poczucia winy, decydują się na wspólną ucieczkę. Jak stwierdza Julia:

[...] to nie jest normalne. Nie możemy się kłócić jak normalna para, ani nawet mieć zwykłego romansu. Nie wiem, co ty masz w głowie, ale ja ani razu nie pomyślałam: „zdradziłam narzeczonego”. Ja zawsze myślę: „zdradziłam narzeczonego z własnym bratem”. [...] - To jest do zniesienia tylko w trakcie - dodała. - Nie umiemy się kumplować. Nie umiemy się pieprzyć bez poczucia winy. Nie możemy ze sobą być, bo za to się idzie do więzienia. Możemy się tylko nie widywać w ogóle?

\footnotetext{
${ }^{6}$ Zagadka blizny Julii, jak i sekret dotyczący skrzętnie skrywanej przez bohaterkę przeszłości znajdują wyjaśnienie w czwartym tomie serii zatytułowanym Grób.

${ }^{7}$ G. Grzegorzewska, Kamienna noc, Kraków 2016, s. 340-341.
} 
Wątek kazirodczego związku tej dwójki nie pełni jedynie funkcji kontrowersyjnego pławika, który ma przyciągnąć coraz to mniej zaskoczonego fabularnymi zwrotami akcji, a coraz bardziej wymagającego czytelnika kryminału. Zakazany związek pomiędzy siostrą i bratem, oprócz tego, że pociąga za sobą konsekwencje dla bohaterów, odnosi się także do zagadnienia winy i kary, do etycznego wymiaru powieści. Według Stanko Lasicia kara stanowi element powieści kryminalnej, za pomocą którego pisarz wyraża swoją koncepcję życia i społeczeństwa ${ }^{8}$. W przypadku $\mathrm{Ka}$ miennej nocy motyw ten nie jest jednak aż tak mocno wyeksponowany jak w powieściach Agathy Christie, czy we współczesnych kryminałach skandynawskich. Grzegorzewska nie sili się na diagnozowanie społeczeństwa czy przedstawianie jednoznacznych poglądów na kwestię dobra i zła. Hołduje zasadzie, że sprawiedliwość - w powieści kryminalnej - może być niesprawiedliwością, a ominięcie sprawiedliwości - sprawiedliwością ${ }^{9}$ Julia sama wymierza karę zbrodniarce uwikłanej w sprawę Bazyliszka, po czym na mocy umowy zawartej ze swoim mężem (będącym jednocześnie policjantem) ucieka z miejsca zdarzenia. I choć taki obrót spraw w kryminale nie dziwi, to w przypadku Grzegorzewskiej warto zwrócić uwagę na bohaterów, którzy wymykają się schematom tak charakterystycznym dla powieści kryminalnej. Autorka ukazuje Julię i Profesora niczym parę bohaterów greckiej tragedii. Takie skojarzenie nie jest zbyt odległe, bowiem tak poprowadzony wątek romansowy znany jest z greckich tragedii bazujących na schemacie „miłości z przeszkodami”, nieczęsto - warto dodać - wykorzystywanym w kryminale ${ }^{10}$. Grzegorzewska przekonuje, że choć obecne decyzje są ich własnym wyborem, bohaterowie nie są winni, że się w sobie zakochali. Los okrutnie sobie z nich zakpił, nie wiedzieli bowiem, że są ze sobą spokrewnieni. Gdyby nie kłamstwa ojca Julii może wszystko potoczyłoby się zupełnie inaczej. Bohaterowie Grzegorzewskiej są więc już od lat nastoletnich w pewien sposób wykolejeni, skrzywieni i skazani na mrok: „Jedni się rodzą dla jasności, inni dla nocy i ciemności”11. Ścieżka, jaką wybrali Julia i Profesor wymaga pozostawienia za sobą wszystkiego, co do tej pory znali, żeby uniknąć konsekwencji zakazanego związku, musza wyjechać z kraju, stale zmieniają miejsca pobytu i tożsamość.

Oprócz motywu winy i kary u Grzegorzewskiej pojawia się także motyw maski, uzasadniony tu dodatkowo weneckim karnawałem. Nieustanna gra pozorów i lawirowanie między coraz to nowymi osobowościami stawiają bohaterów w trudnym położeniu:

Karnawał. Odwrócona rzeczywistość. Ona sama stara się unikać tego święta, co w tym mieście nie jest takie proste. Nie potrzebuje ciągłego przypominania, że jej świat ma niewiele wspólnego z zabawą, a udawanie kogoś, kim się nie jest, obejmuje okres o wiele dłuższy niż jeden miesiąc. I że gdy zdejmuje się maskę, to tylko po to, by nałożyć inną ${ }^{12}$.

Przywdziewanie kostiumów i zakładanie masek staje się dla Julii i Profesora codziennością do tego stopnia, że zapominają o swoim prawdziwym ja. Właściwie „po co nosić maskę, gdy nie ma

\footnotetext{
${ }^{8}$ Zob. S. Lasić, Poetyka powieści kryminalnej. Próba analizy strukturalnej, Warszawa 1976, s. 125.

${ }^{9}$ Lasić w swojej książce zwraca uwagę, że granice między dobrem a złem i sprawiedliwością a niesprawiedliwością są rozmyte i nie zawsze klarowne. Zob. tamże, s. 126.

${ }^{10} Z$ Zb. A. Gemra, Diagnoza rzeczywistości: wspótczesna powieść kryminalna sensacyjno-awanturnicza (na przykładzie powieści skandynawskiej), [w:] Śledztwo w sprawie gatunków. Literatura kryminalna, red. A. Gemra, Kraków 2014, s. 47.

${ }^{11}$ Cytat pochodzi z powieści Agathy Christie Noc i ciemność. Jednocześnie jest parafrazą wersetu z wiersza Williama Blake’a Wróżby niewinności, który w polskim tłumaczeniu brzmi tak: „Jedni się rodzą dla radości, inni dla nocy i ciemności”. G. Grzegorzewska, Kamienna noc, s. 351.

${ }^{12}$ Tamże, s.13.
} 
się już twarzy?”13. Tak naprawdę Julia „nosiła maskę” dużo wcześniej: „Jak na razie była dokładnie taka, jak o niej gadano. Wyniosła, chamska i pewna siebie. Powinna być chyba trochę bardziej załamana, ale [...] pewnie się popisuje. Wkrótce się przekonam, czy jest równie harda, gdy się jej wydaje, że nikt na nią nie patrzy". Tak postrzega Julię dziennikarka, Eliza Florek, która, nie znając wcześniej Julii, decyduje się nawiązać z nią współpracę w sprawie Bazyliszka ${ }^{14}$. Misternie uszyta fasada z kłamstw rozpada się jedynie w obecności Profesora, który im dłużej ucieka wraz z Julią, tym bardziej zadaje sobie sprawę, że nie zna jej tak doskonale, jak mu się wydawało.

Zastanawiające i bardzo nietypowe w kontekście powieści kryminalnej są nie tylko relacje łączące tę dwójkę, ale i oni sami. Chociaż historię w dużej mierze czytelnik poznaje z perspektywy Profesora, to Julia jest postacią, o której dowiaduje się on najwięcej. Wszelkie przemyślenia Łukasza dotyczą Julii i jej zachowania bądź aktualnych zwrotów fabularnych. O Profesorze jako głównym bohaterze wiadomo właściwie niewiele. Jest raczej typem samotnika, który prócz matki i Kojaka, przyjaciela z Osiedla, ma tylko Julię. Bez wątpienia jest człowiekiem inteligentnym - stąd przestępcza ksywka Profesor - sprytnym i kiedy trzeba bezwzględnym, niestroniącym od przemocy. W przeciwieństwie do Julii kieruje się jednak pewnymi zasadami. Dlatego też bohaterowie nie zawsze są w stanie się porozumieć. Profesor nie uznaje ludzi bez zasad, których słowa nic nie znaczą. Obserwując dotychczasowe poczynania Julii, daje jej jasno do zrozumienia, że chwilowo za taką osobę Julię właśnie uważa ${ }^{15}$.

W związku tej dwójki ważną rolę odgrywa też przemoc, która stanowi nieodłączny element powieści kryminalnej, a nawet może stanowić o jej powodzeniu ${ }^{16}$. Grzegorzewska intencjonalnie epatuje makabrą, a sceny przemocy ukazuje w sposób hiperbolizowany, charakterystyczny dla nurtu w kinie włoskim, zwanego giallo, co współgra z filmowością jej powieści ${ }^{17}$. Zarówno Julia, jak i Profesor zdają się przemocą przesiąknięci. Nawet względem siebie zachowują się agresywnie, a opisy tych scen są nader brutalne:

Ogarnia mnie wściekłość. Chwytam ją za gardło. Bije mnie na oślep, ale brakuje jej tchu. Puszczam ją. Opada na podłogę i kaszle, trzymając się za szyję. Patrzy na mnie. Teraz z lękiem. Już to kiedyś widziałem. Szarpię ją za włosy. Krzyczy z bólu. Ale ten krzyk się urywa, gdy znowu uprzytamnia sobie, że w domu są ludzie. Znakomicie. Bardzo mi to na rękę. Niech zachowuje te swoje pozory. Ciągnę ją za sobą w kierunku łóżka. Otwieram szufladę i znajduję kajdanki. Widząc to, zaczyna się wyrywać i szamotać, a robi to w kompletnej ciszy, słyszę jedynie jej przyspieszony oddech. Jest coś przerażającego w tym niemym krzyku. Człowiek nie może przestać się zastanawiać, co musiałby jej zrobić, żeby straciła kontrolę i zaczęła naprawdę krzyczeć ${ }^{18}$.

Pomimo całej brutalności, ciągłych kłamstw i ukrywania przed sobą prawdy, relacja Julii i Profesora nadal trwa. Bohaterowie nie są w stanie żyć bez siebie i czynią wszystko, by móc wreszcie być razem, nie bacząc na grożące im prawne konsekwencje. Chronią siebie nawzajem i są

\footnotetext{
${ }^{13}$ E. Cioran, Zeszyty 1957-1972, Warszawa 2004, s. 549.

${ }^{14}$ G. Grzegorzewska, Kamienna noc, s. 137.

${ }^{15}$ Tamże, s. 232.

${ }^{16} \mathrm{O}$ zbrodni jako zaspokojeniu sadystycznej wyobraźni czytelnika i sadyzmie jako gwarancji sukcesu pisze Wacław Forajter, zob. W. Forajter, „Zły” Leopolda Tyrmanda jako literatura środka. Teksty i konteksty, Kraków 2007, s. 68.

${ }^{17} \mathrm{~A}$. Mazurkiewicz, Tendencje rozwojowe współczesnej polskiej literatury kryminalnej, [w:] Śledztwo w sprawie gatunków..., s. 151.

${ }^{18}$ Tamże, s. 59.
} 
gotowi na wiele poświeceń. Julia, która jest przekonana, że Profesor zginął, prowadzi nawet prywatną vendettę, by pomścić ukochanego (brata) ${ }^{19}$.

Zarówno Julia, jak i Profesor, zawsze na pierwszym miejscu stawiają siebie i swoje własne życie. Ich celem jest przetrwanie. Choć w przypadku Julii zyskuje to nieco bardziej radykalny wymiar, co widać chociażby na przykładzie dialogu między Julią a jej mężem Aaronem, którego porzuciła:

- [...] Znasz mnie. Byle przetrwać.

- Jak daleko się posuniesz, byle przetrwać?

- Jak daleko będzie trzeba. Nie jesteś w stanie mnie przestraszyć ani upokorzyć. Wyobrażasz sobie pewnie teraz różne rzeczy, do których według ciebie jestem zdolna i które mogłam robić, prawda?

- Niczego sobie nie wyobrażam.

- O czymkolwiek byś pomyślał, wiedz, że prawda jest o wiele gorsza.

- Widzę, że jesteś z siebie dumna. I co? Warto było?

- Lepiej być panem w piekle niż niewolnikiem w niebie ${ }^{20}$.

Właśnie to ostatnie zdanie bardzo dobrze oddaje różnice między bohaterami Grzegorzewskiej a typowym głównym bohaterem powieści kryminalnej. Ani Julia, ani Profesor nie postępują według zasad, jakimi kierują się przedstawiciele prawa, czy nawet detektywi(-amatorzy) ${ }^{21}$. W przeciwieństwie do Herkulesa Poirot, Anastazji Kamieńskiej czy Harry’ego Hole’a, którzy dążą do wymierzenia sprawiedliwości, ukarania winnych i przywrócenia pewnego stałego porządku rzeczy, ten duet postępuje według własnych reguł22. Bohaterowie Grzegorzewskiej nie mają głęboko zakorzenionego poczucia sprawiedliwości, nie kierują się żadnym moralnym kompasem. Julii bardziej zależy na odkryciu prawdy aniżeli na ukaraniu sprawcy. Bohaterowie Kamiennej nocy nie są jednowymiarowi, a ich motywy nie są jednoznaczne. Świat, w którym żyją, choć nieco ubarwiony i przasadnie komiksowy, odznacza się wieloma odcieniami szarości: „Świat grozy, krwi, przemocy i powagi jednocześnie jest światem karykatury, grymasu, pełnego wyższości uśmiechu i beznadziejnej pogardy”23. Kamienna noc jest taką właśnie mieszanką, gdzie nic nie jest takie, jakim się wydaje.

\footnotetext{
${ }^{19}$ Stosunek Julii do Profesora ulega zmianie na przestrzeni całego cyklu. Dopiero w Kamiennej nocy Julia zdaje sobie sprawę, jak ważny jest dla niej Łukasz, gdy jest przekonana, że bezpowrotnie go utraciła: „Wiktor, Marcelina, Aaron, matka, ojciec - stawali się coraz bardziej rozmyci i nierealni. Niepotrzebni i nieważni. Łukasz to co innego. Zostanie we mnie na długo. Pewnie na zawsze. Tak musiało być. Ale reszta? To tylko pionki w grze", G. Grzegorzewska, Kamienna noc, s. 404.

${ }^{20}$ Tamże, s. 130 .

${ }^{21}$ We współczesnych kryminałach postać detektywa nadal jest silnie zakorzeniona, ale coraz częściej zastępują ją specjaliści medycyny sądowej (Kay Scarpetta z powieści kryminalnych Patricii Cornwell - pierwsza część cyklu nosi tytuł Postmortem), policyjni psychologowie, profilerzy (Sasza Załuska z cyklu „Cztery żywioły Saszy Załuskiej” Katarzyny Bondy: Pochłaniacz, Okularnik, Lampiony, Czerwony Pajq̨k) oraz przedstawiciele wymiaru sprawiedliwości (Teodor Szacki z kryminalnej trylogii Zygmunta Miłoszewskiego: Uwikłanie, Ziarno prawdy, Gniew) czy nawet dziennikarze (Mikael Blomkvist z serii „Millennium” Stiega Larssona) - choć w tym przypadku, trzeba przyznać, że postać Salander jest mocniej zaakcentowana.

${ }^{22}$ Reprezentantami takiego modelu postępowania w powieści kryminalnej są Philip Marlowe oraz Mistrz, bohater kryminalnej trylogii Marcina Świetlickiego Jedenaście, Dwanaście, Trzynaście, którego twórczość stanowi ważny punkt odniesienia dla Gai Grzegorzewskiej (w Kamiennej nocy pojawiają się odwołania do poezji Świetlickiego). Warto nadmienić, że Grzegorzewska wraz z Marcinem Świetlickim i Ireneuszem Grinem napisali kryminał zatytułowany Orchidea.

${ }^{23}$ S. Lasić, Poetyka powieści kryminalnej..., s. 100.
} 
Odejście od typowej dla gatunku schematyczności w Kamiennej nocy ujawnia się także w kompozycji tekstu oraz w konstrukcji płaszczyzny fabularnej. Do momentu powstania tej powieści fabuły kryminałów Gai Grzegorzewskiej, określane mianem „krakowskich”, osadzone były w Krakowie ${ }^{24}$. Osadzanie akcji w rzeczywistym mieście jest w pewnym stopniu wymogiem gatunku ${ }^{25}$. Taki zabieg pozwala odnieść powieściowe wydarzenia do konkretnych miejsc, a tym samym daje czytelnikowi poczucie realności ${ }^{26}$. Dlatego też niestandardowym posunięciem jest umieszczenie fabuły w kilku miejscach, co w Kamiennej nocy zastosowała Gaja Grzegorzewska.

Rezygnacja $\mathrm{z}$ jednego miejsca akcji na rzecz rozproszenia jej na kilka innych przestrzeni jest zabiegiem ryzykownym, zwłaszcza w powieści kryminalnej, która odznacza się uporządkowaniem i logiką kompozycji. Grzegorzewska wprowadza zaś podział nie tylko w elemencie „przestrzennym" fabuły, ale i czasowym. Powieść ma kompozycję klamrową. Kończy i zaczyna się w Wenecji w styczniu 2016 roku. Wydarzenia fabularne spaja ze sobą karnawał, które to święto autorka wybrała nie bez powodu. Karnawał jest czasem przebierania i zakładania masek, ale z chwilą, kiedy się kończy, maski opadają. Podobnie jest w przypadku bohaterów, którzy po licznych przejściach spotykają się, by zaprzestać kłamstw i ostatecznie wszystko sobie wyjaśnić.

Struktura opowieści dzieli się na trzy linie fabularne. Pierwsza z nich obejmuje sześć miesięcy, druga sześć dni (wydarzenia przedstawione są tu od końca), a trzecia sześć godzin (rozdział Klamra). Całość jest pomyślana i napisana retrospektywnie (dominuje narracja linearno-powrotna). Najpierw pojawia się prolog, który odnosi się do roku 2014, czyli wydarzeń najwcześniejszych. W Kamiennej nocy dwa razy pojawia się rozdział zatytułowany Godzina zero, na początku i na końcu powieści ${ }^{27}$. Rozdział Godzina zero znajdujący się na początku odnosi się do wydarzeń z 29 czerwca 2015, które rozegrały się w Patras w Grecji. Tak samo zatytułowany rozdział, ale znajdujący się na końcu, dotyczy wydarzeń rozgrywających się od 2 października 2015 roku. Po tych rozdziałach występują naprzemiennie rozdziały o numeracji ujemnej i dodatniej, co przywodzi na myśl skojarzenia z poziomami. Rozdziały od minus jeden do minus sześć dotyczą pobytu Julii i Profesora w Patras w 2015 roku. Natomiast poprzeplatane między nimi od jeden do sześć odnoszą się do wydarzeń, które miały miejsce w Krakowie w tym samym roku, już po powrocie Julii do miasta. Zdarzenia w Patras obejmują sześć miesięcy, natomiast te w Krakowie sześć pierwszych dni sierpnia. Epilog wyjaśnia i zespala całą powieść, prowadząc czytelnika do ostatniego, już wspomnianego, rozdziału Klamra. Powieść, jak wyjaśniała sama autorka, ma budowę szkatułkową ${ }^{28}$. Polega ona na skonstruowaniu z kilku odrębnych całostek, które

${ }^{24} \mathrm{~W}$ Żniwiarzu akcja toczy się początkowo w Krakowie, by następnie przenieść się do podkrakowskiej wsi.

W Topielicy wydarzenia rozgrywają się niemal w całości na Mazurach. Natomiast w Nocy z czwartku na niedzielę, Grobie i Betonowym pałacu akcja umiejscowiona jest wyłącznie w Krakowie.

${ }^{25}$ Zwłaszcza w przypadku powieści seryjnych, gdzie występuje seryjny bohater. Czytelnicy, podobnie jak autorzy, bardzo szybko przyzwyczajają się do konkretnych miast czy postaci. Przykładem tego typu zabiegu są powieści Katarzyny Puzyńskiej, których akcja osadzona jest w fikcyjnej wsi Lipowo, a także książki z serii z Harrym Hole Czerwone gardło, Trzeci klucz i Pentagram, które w jedenastotomowym cyklu określane są jako „Trylogia z Oslo”.

${ }^{26} \mathrm{~W}$ ostatnich latach bardzo popularne stały się różnego rodzaju spacery śladami bohaterów literackich, w tym postaci powieści kryminalnych. W 2017 roku w ramach pierwszego łódzkiego Festiwalu Kryminału odbyła się wycieczka szlakiem Lampionów Katarzyny Bondy, co wskazuje, jak mocno czytelnicy identyfikują się z kryminalnym miejscem akcji, o którym czytają.

${ }^{27}$ Godzina zero to polskie tłumaczenie tytułu powieści Agathy Christie Towards zero (1944), które określa moment dokonania zbrodni. Chodzi o ukazanie istoty planowania zbrodni, gdyż „sam moment jego dokonania nie jest już tak ważny". A. Gemra, Diagnoza rzeczywistości..., s. 50.

${ }^{28}$ <http://krakow.wyborcza.pl/krakow/56,44425,19997421, gaja-grzegorzewska-kamienna-noc,,1.html> (dostęp 26.03.2018). 
pojawiają się w tekście w sposób nieprzypadkowy, spójnej fabularnie całości. Te całostki mogą przybierać różną formę, ale zasadniczo opierają się na jednym schemacie. Fabuła dotyczy historii A, ale jeden $\mathrm{z}$ bohaterów opowiada historię $\mathrm{B}, \mathrm{w}$ której występuje drugi bohater opowiadający historię $C$.

Takie zabiegi sprawiają, że Kamienna noc jest powieścią niezwykle filmową. Wacław Forajter zauważa: „Poetyka fragmentu odpowiadałaby tutaj szybkiemu, nerwowemu montażowi: najazdom kamery na detale, przewadze planów ogólnych, symultanicznemu przebiegowi kilku wątków"29. I choć uwagę tę Forajter czyni w kontekście Złego Tyrmanda, to bez wątpienia słowa te można odnieść również do Kamiennej nocy.

Oprócz bezpośredniej relacji ze wspólnej ucieczki Profesora i Julii oraz z pobytu w Patras, w powieści znajdują się fragmenty książki, pisanej przez jedną z bohaterek - Elizę Florek, które dotyczą zabójstwa Helenki Karo i sprawy Bazyliszka (gwałciciela i mordercy dzieci), a także wycinki z prasy bulwarowej oraz protokoły przesłuchań. Takie poszatkowanie fabuły (a jest to chwyt przemyślany, gdyż poszczególne elementy układanki łączą się w jedną całość) i gra z konstrukcją w powieści kryminalnej należy do rzadkości, bowiem komplikuje czytelnikowi odbiór całej historii, i zamiast stopniowo wyjaśniać pewne kwestie, nawarstwia wątpliwości i mnoży pytania. Grzegorzewska wystawia na próbę cierpliwość czytelnika i zmusza go do wysiłku, który nie ogranicza się jedynie do poszukiwania odpowiedzi na pytanie, „kto zabił?”. Przemieszanie czasów i przestrzeni zaburza przebieg opowieści, ale jednocześnie pozwala czytelnikowi uzyskać nowe spojrzenie na opowiadaną historię i jej bohaterów.

\section{Intertekstualna podróż przez (pop)kulturowe stany świadomości}

Interesująco wygląda również to, jak Grzegorzewska gra z konwencją kryminalną. Stanko Lasić, jugosłowiański badacz, na którego się już powoływałam, wyróżnia cztery formy powieści kryminalnej, która stanowi jej trzon. Są to: forma śledztwa, pościgu, zagrożenia i akcji. Wypada więc przyjrzeć się, który z wariantów wykorzystała Grzegorzewska i jak go przekształciła na potrzeby Kamiennej nocy.

Forma śledztwa opiera się na czynie zagadkowym (zwanym przez Lasicia tajemniczym), którym najczęściej jest morderstwo ${ }^{30}$. Nie wiadomo jednak, kto ów czyn popełnił ani jakie motywy nim kierowały, celem powieści powinno być więc wykrycie sprawcy i wyjaśnienie pobudek zbrodniczego aktu. Taki schemat nie narzuca jednowarstwowej zagadki, bowiem może zostać wzbogacony o kolejne tajemnicze czyny, które gmatwają przebieg śledztwa. Jak wskazuje Lasić, autor, który wybrał wariant śledztwa z punktem kulminacyjnym na końcu, powinien doprowadzić do wyjaśnienia wszystkich czynów tajemniczych oraz głównej zagadki ${ }^{31}$. Kluczowy jest tu także fakt, że w tej formie kryminału tylko jedna osoba wie, kto popełnił zbrodnię i jest nią sam morderca. Kamienna noc pod pewnymi względami rzeczywiście przypomina formę śledztwa. Julia prowadzi dochodzenie w sprawie zabójstwa Helenki Karo, a po drodze próbuje rozwikłać zagadkę samobójczej śmierci matki dziewczynki oraz odkryć prawdziwą tożsamość Bazyliszka, co można by uznać za kolejne tajemnicze czyny. Do tego schematu nie pasuje jednak kilka kwestii. Przede wszystkim morderców,

\footnotetext{
${ }^{29}$ W. Forajter, „Zty” Leopolda Tyrmanda..., s. 93.

${ }^{30}$ S. Lasić, Poetyka powieści kryminalnej..., s. 74.

${ }^{31}$ Zob. tamże, s. 75.
} 
czy raczej osób zamieszanych w zbrodniczy proceder, jest więcej. Nie jest to do końca sprzeczne ze schematem, jaki zakłada forma śledztwa, ale jak się okazuje, tożsamość mordercy jest znana więcej niż jednej osobie. A to już kłóci się z podstawowymi założeniami tego modelu. Dodatkowo, choć główna zagadka zostaje rozwikłana, nie wszystkie wątki zostają wyjaśnione, a zakończenie (pomimo tego, że otwarte nie jest) sugeruje, że czytelnik spotka się z bohaterami ponownie.

Spośród czterech wariantów wskazanych przez Lasicia, w kontekście Kamiennej nocy można rozpatrywać - prócz formy śledztwa - tylko formę zagrożenia ${ }^{32}$. Według Lasicia formę zagrożenia charakteryzuje czyn zagrażający, a właściwie seria takich czynów, które budzą „niepewność, obawę, poczucie niebezpieczeństwa, [...] powodują niespodziewane zmiany, stają się przyczyną przerażenia i - w końcu - wyniszczającego przeczucia śmierci”33, co odpowiadałoby definicji klasycznego thrillera. Jak wskazuje Lasić, osoba zagrożona za wszelką cenę usiłuje przywrócić zakłócony porządek i wyeliminować zagrożenie poprzez wyjaśnienie, zmienić tajemnicę w prawdę. Przyglądając się wydarzeniom rozgrywającym się w Kamiennej nocy, trzeba przyznać, że właśnie ta forma wydaje się najodpowiedniejsza. Podążając tokiem rozumowania Lasicia, Julię można uznać za osobę zagrożoną, która próbuje przywrócić naruszoną równowagę i dojść do prawdy. W tym względzie, jak słusznie zauważa jugosłowiański badacz, forma zagrożenia przypomina formę śledztwa. Jednakże: „wyjaśnienie nie jest tylko wytłumaczeniem czynu tajemniczego albo zagrażającego (czemu towarzyszy ujęcie zbrodniarza), ale także zmianą struktury świata, przywróceniem porządku, panowaniem człowieka" ${ }^{34}$.

Owszem, Julii udaje się dociec prawdy i wymierzyć sprawiedliwość (a właściwie zemścić się za śmierć Profesora, co napędzało jej działania), ale swoimi poczynaniami wcale nie „przywraca porządku”. Właściwie, to ona tę równowagę zaburza, gdyż z ofiary przeistacza się w kata i odchodzi wolno, nie ponosząc konsekwencji swych działań. Takie rozwiązanie kłóci się z jedną z podstawowych zasad kryminału, dla którego „przestępstwo jest zakłóceniem «porządku świata», lecz porządek ten w powieści kryminalnej zawsze zostaje przywrócony"35. Frapująca jest także kwestia narracji, gdyż pojawia się pytanie, „kto jest najbardziej uprzywilejowany w powieści realizującej formę zagrożenia?”. Oczywiście, taką osobą jest morderca. Istnieje również drugi wariant. Mianowicie, osoby uprzywilejowanej nie ma. Lasić wyjaśnia to następująco:

Czyn zagrażający jest symbolem przeszłości, której jakaś postać wyrzeka się świadomie lub nieświadomie; popełniona zbrodnia wraca w formie zagrożenia. Wymierzone jest ono nie tylko w byłego zbrodniarza (który w tej chwili może już od dawna nie żyje albo wypadł z gry), ale i w niewinnego: nową ofiarę.

\footnotetext{
${ }^{32}$ Forma pościgu nie pasuje do struktury Kamiennej nocy, gdyż już na początku odkrywa tożsamość zabójcy. Punkt ciężkości przesuwa się więc na inne kwestie: czy zbrodniarzowi uda się uniknąć kary oraz czy umknie wymiarowi sprawiedliwości, które to kwestie w Kamiennej nocy pojawiają się, ale są marginalne. Podobnie rzecz się ma z powieścią typu akcja, której osnowę stanowi potencjalny czyn aktualizujący przekształcający się - wraz $\mathrm{z}$ rozwojem fabuły - w czyn realny. Zob. tamże, s. 103.

${ }^{33}$ Tamże, s. 96.

${ }^{34}$ Tamże, s. 97.

${ }^{35}$ W. Bialik, Fryderyka Dürrenmatta polemika z konwencją typowej powieści kryminalnej, [w:] Śledztwo w sprawie gatunków..., s. 80.
} 
Trudno stwierdzić, by w przypadku Kamiennej nocy występowała którakolwiek z tych dwóch możliwości. Wariant z zabójcą (a właściwie zabójcami) nie wchodzi w rachubę, gdyż jest on postacią całkowicie poboczną i nie ma większego znaczenia dla fabuły. Natomiast nie można powiedzieć, by w powieści nie było osoby uprzywilejowanej. Nie ulega wątpliwości, że jest nią Julia Dobrowolska. Jako jedyna bierze udział we wszystkich wydarzeniach (tych, które miały miejsce w Krakowie, i tego, co rozgrywało się już po ucieczce bohaterów), manipuluje, kłamie i planuje, a nawet przewiduje pewne wypadki.

Grzegorzewska nie wybiera więc konkretnego wariantu. W swojej powieści łączy elementy formy śledztwa i zagrożenia, a wszystko gmatwa, dodatkowo zaburzając chronologię wydarzeń i wprowadzając nietypową narracją. W rozdziałach o numeracji dodatniej, obok pierwszoosobowej narracji Florek, zostaje wprowadzony narrator trzecioosobowy, który odsłania przed czytelnikiem powody, dla których Julia zmuszona była opuścić Kraków. Natomiast w rozdziałach o numeracji ujemnej mamy do czynienia z narratorem pierwszoosobowym, którym jest Profesor. Poprowadzenie narracji w taki sposób jest charakterystyczne dla kompozycji ramowej. Pierwszy narrator jest najczęściej wszechwiedzący, „otwiera” i „zamyka” utwór. Drugi zaś lub kolejny (najczęściej jest nim jeden z głównych bohaterów) opowiada właściwą akcję. Narracja jest bardzo ważnym punktem kryminalnej opowieści, gdyż - jak pisze Anna Piwowar:

[...] jawi się jako zbiór znaków, a przeprowadzane przez narratorów śledztwa mają [...] tekstowy charakter. Świat nie dość, że objawia się poprzez teksty, to także sam zostaje nasycony znakami. Skoro więc świat postrzegany jest jako zestaw gotowych fabuł, a granica pomiędzy fikcją a realnością zostaje zatarta, jedyną drogą dotarcia do sensu jest narracja, przetworzenie zastanych historii we własną opowieśćc ${ }^{36}$.

Spoiwem całej fabuły Kamiennej nocy staje się właśnie narracja, która sama w sobie jest tropem zawierającym wskazówki do rozwikłania zagadki. Wprowadzenie trzech narratorów zmienia czytelniczą perspektywę. Wydarzenia przedstawiane z punktu widzenia wszechwiedzącego narratora nadają pełne rysy opowiadanej historii. Natomiast uczynienie z postaci Profesora narratora tę perspektywę nieco ogranicza. Czytelnik nie ma bowiem wglądu w myśli i działania innych bohaterów za wyjątkiem tych sytuacji, których świadkiem bądź uczestnikiem jest Łukasz. Pozwala to jednak lepiej przyjrzeć się tej postaci oraz relacjom jego i Julii, która w poprzednich częściach stanowiła centrum opowieści. Przyglądając się zdarzeniom z perspektywy Łukasza, czytelnik jest trochę jak sam bohater. Nieco zagubiony, podejrzliwy, pozostawiony sam sobie, niby uczestniczący w fabule, ale jednak będący poza nią. Jak stwierdza sam Łukasz: „To nie tak, że ignoruję znaki albo ich nie widzę. Tylko źle je odczytuję. Gdy cały czas masz z tyłu głowy, że sowy nie są tym, czym się wydają, zapominasz, że czasami cygaro jest tylko cygarem"37.

Od fałszywych tropów w Kamiennej nocy aż się roi, nic więc dziwnego, że skołowany jest nie tylko bohater, ale i czytelnik. Jedną z pułapek interpretacyjnych jest postać wspomnianej już

\footnotetext{
${ }^{36}$ A. Piwowar, Tropienie innego, „Podteksty” 2009, nr 1(15), <http://podteksty.amu.edu.pl/podteksty/?action=dyn amic\&nr=16\&dzial=4\&id=357> (dostęp 26.03.2018).

${ }^{37}$ Słowa „sowy nie są tym, czym się wydają" są nawiązaniem do słynnego serialu Davida Lyncha zatytułowanego Miasteczko Twin Peaks, które dziś uważane jest za pewnego rodzaju gatunkową hybrydę. G. Grzegorzewska, Kamienna noc, s. 70.
} 
Elizy Florek - dziennikarki brukowej gazety „Szperacz Codzienny”38 - która we współpracy z Julią zbiera materiał do swojej sensacyjnej książki o sprawie Bazyliszka. Celem tej publikacji jest także próba rehabilitacji wizerunku Dobrowolskiej. Jak się jednak okazuje, osoba taka jak Eliza Florek nie istnieje. Jest to kolejna wykreowana przez Julię postać, której prawdziwa tożsamość stanowi jeden z bardziej zaskakujących twistów Kamiennej nocy. W zeznaniach z przesłuchań Elizy Florek kryją się informacje z pozoru mało znaczące. Jednakże niektóre z nich mogą sugerować, zaznajomionemu z książkami Grzegorzewskiej czytelnikowi, prawdziwą tożsamość Elizy. Prowadząc śledztwo, dziennikarka zawsze pojawiała się w towarzystwie Julii. Przynajmniej tak to przedstawia trzecioosobowy narrator. Dopiero w jednym z ostatnich protokołów okazuje się, że tam, gdzie pojawiały się rzekomo Julia i Eliza, znajdują się odciski palców tylko jednej osoby - Elizy Florek, co jeszcze bardziej komplikuje wielowarstwową zagadkę.

Obok zawartych w samej narracji wskazówek interpretacyjnych ważną funkcję w utworze pełnią motta poszczególnych rozdziałów, które stanowią ich dopełnienie. Grzegorzewska umieszcza motta właściwie w każdym rozdziale. Nawiązuje w nich do literatury (Biesów Fiodora Dostojewskiego, Imienia róży Umberta Eco czy Czekając na Godota Samuela Becketta), ale także do szeroko rozumianej popkultury: cytatów z filmów, seriali czy tekstów piosenek Iggy'ego Popa, Davida Bowiego oraz zespołu The Chemical Brothers.

Każde z zawartych w powieści mott stanowi ilustracje tego, co wydarza się w poszczególnych rozdziałach. Tytuł książki pisanej przez Elizę Florek brzmi Bazyliszek. W pogoni za cieniem. Pod tak zatytułowanym fragmentem widnieje ustęp z wiersza Francisca de Queveda y Villegasa $\mathrm{Ba}$ zyliszek. Scenę postrzelenia Profesora w rozdziale Godzina zero odpowiednio ilustruje cytat z filmu Bulwar Zachodzqcego Słońca: „Zabawne, jak delikatni mogą być ludzie, kiedy jesteś martwy”39. Natomiast w rozdziale zatytułowanym tak samo, ale znajdującym się niemal na końcu książki, słowa z filmu Frankenstein „To żyje! To żyje!” ujawniają, że Profesor przeżył postrzały i - wydawałoby się - śmiertelny upadek. Rozdział minus dwa, w którym czytelnik dowiaduje się najwięcej o pobycie i relacji między Julią a Profesorem obrazują słowa piosenki Take Me to Church:

"We were born sick"

You heard them say it

My church offers no absolutes

She tells me "worship in the bedroom"

The only heaven I'll be sent to

Is when I'm alone with you

I was born sick, but I love it

Słowa „The only heaven I'll be sent to/Is when I'm alone with you” oddają istotę relacji Julii i Profesora. Ich więź jest bardzo silna, co niejednokrotnie potwierdza sama Julia: „Pozwoli-

\footnotetext{
${ }^{38}$ „Szperacz Codzienny” jest gazetą brukową, której dziennikarze gonią za tanią sensacją i skandalem w celu "obsmarowania” znanych i lubianych. Artykuły „Szperacza Codziennego” są stylizowane na teksty prasy bulwarowej jak te zamieszczane w „Fakcie” czy „Super Expressie”. W artykule ze „Szperacza” można odnaleźć pomyłki typowe dla tego rodzaju dziennikarstwa - raz pojawia się informacja, że brat Julii nazywa się Łukasz B., a innym razem - w tym samym artykule - Łukasz D. Zob. tamże, s. 103

${ }^{39}$ Tamże, s. 30.
} 
łam sobie na emocje i myśli, które pewnie każdy uznałby za niezdrowe. Wyobraziłam sobie, że znowu leżę przytulona do boku mojego brata, czas nie istnieje, nie ma dni ani miesięcy" ${ }^{40}$.

W motcie do rozdziału minus pięć pojawia się piosenka z filmu Django (2012) zatytułowana Freedom, w której wybrzmiewają słowa:

... But I've gone too far to go back now

... I am looking for freedom, looking for freedom...

And to find it cost me everything I have...

Odpowiada ona nastrojowi Julii, która jest przekonana, że straciła Profesora, próbuje więc doprowadzić do końca swą prywatną vendettę i nie cofnie się przed niczym, by tego dokonać. Tylko zemsta może przynieść jej ukojenie, zapewnić upragnioną wolność, o której śpiewają Anthony Hamilton i Elayna Boynton.

Intertekstualność nie zawiera się jedynie w mottach, ale jest obecna w całej powieści Grzegorzewskiej. Współczesna powieść kryminalna zdaje się mocno zanurzona w (pop)kulturze, ale intertekstualność nie jest jej dominującą cechą - choć wpływ intertekstualności na powieść kryminalną jest coraz większy. Można to zauważyć już w polskiej odmianie kryminału ${ }^{41}$.

W przypadku Kamiennej nocy jest nieco inaczej niż w większości innych współczesnych kryminałów, które fabułę opierają na śledztwie i temu aspektowi podporządkowują pozostałe wątki fabularne. Grzegorzewska skupia się bardziej na relacjach między dwójką protagonistów i kontrowersyjnym wątku romansowym aniżeli na intrydze kryminalnej. Dodatkowo prowadzi z czytelnikiem grę i umieszcza w swej książce liczne (pop)kulturowe smaczki. Dlatego też Kamiennq noc można by określić mianem „worka”, którego podstawowym wyznacznikiem byłaby właśnie intertekstualnośćc ${ }^{2}$.

Pod względem intertekstów Kamienna noc jest bardziej przemyślana i mniej oczywista niż poprzednie książki Grzegorzewskiej. W tamtych roiło się przede wszystkim od literackich odniesień, głównie od cytatów z powieści Agathy Christie czy nawiązań do Sherlocka Holme$\mathrm{sa}^{43}$. Dopiero w Betonowym pałacu pojawiły się muzyczne i filmowe inspiracje. Osobisty gust w przypadku Grzegorzewskiej ma ogromne znaczenie. Grzegorzewska wysoko ceni sobie poezję T.S. Eliota, dlatego też to właśnie z jego wiersza uczyniła motto całej powieści. Kamiennq noc otwiera motto zaczerpnięte z wiersza East Coker $^{44}$ T.S. Eliota:

\footnotetext{
${ }^{40}$ Tamże, s. 398.

${ }^{41}$ Nagromadzenie intertekstów nie jest ani tak duże w twórczości innych pisarzy, ani tak widoczne jak u Grzegorzewskiej, ale występuje. Remigiusz Mróz w serii swoich thrillerów prawniczych często odwołuje się do powieści Cormaca McCarthy'ego. Jeden z pobocznych bohaterów tego cyklu zaczytuje się w książkach McCarthy'ego takich jak Droga. Z tego powodu nazywany jest Kormakiem. Z kolei Zygmunt Miłoszewski, umieszczając akcję Ziarna prawdy w Sandomierzu, prześmiewczo i ironicznie przywołuje polski serial kryminalny Ojciec Mateusz i Artura Żmijewskiego, wcielającego się w rolę tytułowego księdza. Na razie takich przykładów nie ma zbyt wiele w polskiej odmianie, ale tendencja do zamieszczania intertekstów zdaje się zwiększać.

${ }^{42}$ Określeniem „worek” w odniesieniu do Złego Tyrmanda posłużyła się Jolanta Pasterska, a powtórzył je w swojej książce Wacław Forajter, zob. W. Forajter, „Zty” Leopolda Tyrmanda..., s. 141.

${ }^{43} \mathrm{~W}$ Kamiennej nocy też pojawia się nawiązanie do Sherlocka, zob. s. 12.

${ }^{44}$ G. Grzegorzewska, Kamienna noc, s. 5.
} 
Wiedza czerpana z doświadczenia ma, jak się nam zdaje, Wartość w najlepszym razie zgoła ograniczoną.

Wiedza narzuca schemat, a przez to kłamie, Bo schemat zmienia się z każdą chwilą.

A każda chwila w nowy i gorszący sposób

Przewartościowuje to wszystko, czym byliśmy.

Zawodu nie sprawia tylko to, co swym oszustwem nie może

Już zaszkodzić.

Wiersz bardzo dobrze odzwierciedla wszystko to, co dzieje się na płaszczyźnie kompozycyjnej tekstu („schemat zmienia się z każdą chwilą”), ale również współbrzmi z wydarzeniami fabularnymi. Po przeczytaniu całości nie sposób nie odnieść wrażenia, że każde zdarzenie przewartościowało „to wszystko, czym byliśmy”, a właściwie, czym byli Julia i Profesor. Dodatkowo w jednej ze scen, na półce z książkami obok Opowieści o dwóch miastach, Wilka stepowego, Obcego i Śmierci w Wenecji, pisarka umieściła zniszczony tomik Eliota, by podkreślić istotę jego twórczości ${ }^{45}$. Dla Eliota charakterystyczne było łączenie awangardy i tradycji oraz czerpanie z kultury europejskiej i orientalnej. Eliota interesował również człowiek i jego zagubienie w świecie, toteż portretowani przez niego bohaterowie są pozbawieni heroizmu i sceptyczni, nie do końca potrafiący się odnaleźć w otaczającej ich rzeczywistości. Dodatkowo, od wczesnej twórczości Eliota fascynowała brzydota i ohyda, czego dawał wyraz w swoich utworach. Wszystko to, co budziło zainteresowanie Eliota, znalazło odzwierciedlenie u Grzegorzewskiej.

Znaczna część intertekstów w Kamiennej nocy to nawiązania popkulturowe, które Grzegorzewska z rozmysłem podrzuca czytelnikowi. Większość tych odwołań jest podana wprost: „Podpis głosił: «Polska Gra o tron. Jaime i Cersei dla ubogich» ${ }^{46}$. O ile jednak część osób zna (choćby ze słyszenia) Grę o tron, jedynie fani będą wiedzieć, skąd takie porównanie ${ }^{47}$. Podobnie rzecz się ma z przywołaniem kultowych już postaci z Władcy Pierścieni: „Obserwuję ją, jak wstaje, powoli, niby nic. I nagle rzuca się na mnie jak Bilbo Baggins na Frodda" ${ }^{48}$. Fani ekranizacji nie będą musieli się zastanawiać, którą filmową scenę Grzegorzewska przywołuje. Filmowych odwołań w Kamiennej nocy jest znacznie więcej. Można doszukać się nawiązań do Predatora, Thelmy i Louise, ponownie Wtadcy Pierścieni, Batmana, Pięknej i bestii czy Mad Maxa ${ }^{49}$. Niektóre (pop) kulturowe tropy są nieco bardziej zawoalowane: „Jest tylko czarna dziura, jak w kapturze Dementora" ${ }^{50}$, ale uniwersum świata Harry'ego Pottera tak mocno osiadło w naszej kulturze, że każdy czytelnik odgadnie, do czego Grzegorzewska się odnosi.

W Kamiennej nocy nie brak też typowo literackich nawiązań, poprzez które autorka pokazuje, co było i nadal jest dla niej ważne, na czym się wychowała i co wpłynęło na jej pisarski back-

\footnotetext{
${ }^{45}$ Poezja T.S. Eliota stanowi motyw przewodni dla Grzegorzewskiej w Kamiennej nocy, ale nie pojawia się aż tak często. Jak podkreślała pisarka przy okazji spotkań z czytelnikami, na twórczości Eliota oprze ostatnią część trylogii z Julią Dobrowolską i Profesorem, której ani data wydania, ani tytuł obecnie nie są znane.

${ }^{46}$ G. Grzegorzewska, Kamienna noc, s. 78.

${ }^{47}$ Serialowi Jaime i Cersei - podobnie jak Julia i Profesor - byli rodzeństwem, które żyło w kazirodczym związku (owocem którego były dzieci - zupełnie jak w przypadku bohaterów Kamiennej nocy).

${ }^{48}$ Tamże, s. 58.

${ }^{49}$ Zob. tamże, s. 105, 106, 163, 20, 432 i 138.

${ }^{50}$ Tamże, s. 120.
} 
ground. Grzegorzewska wciąż pozostaje wierna królowej kryminału, ale tym razem czyni to nie poprzez dosłowne przytaczanie motywów Christie, ale za pomocą nawet nieco ironicznych porównań: „Ostrożnie otwiera kopertę i z namaszczeniem tak wielkim, jakby się spodziewała znaleźć w środku list z gratulacjami od samego Herkulesa Poirot" ${ }^{51}$. Podobnie ironiczny stosunek Grzegorzewska ma do narodowego dobra, jakim jest epopeja Adama Mickiewicza, a właściwie do jej ekranizacji: „Rezultat jest taki, że ona zna ze trzy litewskie przekleństwa, a ja, że Litwo ojczyzno moja, ksiądz Robak, Bogusław Linda, Alicja Bachleda-Curuś”52. Oprócz poezji Eliota, pojawia się nawiązanie do Szekspirowskiej Ofelii, postaci Philipa Marlowe'a oraz do twórczości Marcina Świetlickiego, którego autorka bardzo sobie ceni ${ }^{53}$.

W przypadku Kamiennej nocy intertekstualność stanowi dodatkowy walor. Interteksty dobrze komponują się z zestawionymi fragmentami, a ich nawarstwienie nie rozprasza czytelnika, jak to miało miejsce w Betonowym pałacu. Większość twórców współczesnej polskiej powieści kryminalnej stara się osadzić fabułę w konkretnej sytuacji społeczno-politycznej (Katarzyna Bonda w Okularniku poruszyła kwestię ruchów narodowo-wyzwoleńczych, Remigiusz Mróz w jednej ze swych licznych powieści zajął się problemem uchodźctwa), a grę z czytelnikiem podejmują wyłącznie na poziomie intrygi kryminalnej. Natomiast Gaja Grzegorzewska nie sili się na stawianie diagnozy czy próbę odmalowania problemów polskiego społeczeństwa. Podąża za gatunkiem, a jednocześnie wytycza własną kryminalną ścieżkę. Przewrotność, mylenie tropów i wodzenie czytelnika za nos są wpisane w ramy gatunku, jakim jest powieść kryminalna. Im trudniejsza i bardziej skomplikowana zagadka, im więcej twistów, tym większa aprobata czytelników. Autorzy współczesnych kryminałów prześcigają się w coraz to wymyślniejszych eksperymentach, by zadowolić tych, którzy zaczytują się w ich powieściach. Nie inaczej jest w przypadku Gai Grzegorzewskiej i Kamiennej nocy, którą można by określić takim właśnie gatunkowym eksperymentem.

\footnotetext{
${ }^{51}$ Tamże, s. 166.

${ }^{52}$ Tamże, s. 171.

${ }^{53}$ Tamże, s. 27, 425, 128.
} 


\title{
SŁOWA KLUCZOWE:
}

\author{
powieść kryminalna
}

\begin{abstract}
Abstrakt:
Celem artykułu jest przyjrzenie się współczesnej polskiej powieści kryminalnej w kontekście samoświadomości gatunku na przykładzie kryminału Gai Grzegorzewskiej Kamienna noc. Wychodząc od tradycji gatunkowej i twórczości Agathy Christie, tekst wskazuje na zbieżności i rozbieżności między powieścią Grzegorzewskiej a tradycyjnie pojmowanym kryminałem. $W$ artykule zostały zanalizowane podstawowe dla powieści kryminalnej kwestie, takie jak: warstwa fabularna, narracja, kompozycja oraz wykorzystanie konwencji jako elementu odwoływania się do tradycji kryminału, a zarazem elementu stanowiącego dla Grzegorzewskiej warstwę eksperymentalną, do której odnieść można, mający coraz większe znaczenie dla polskiej odmiany gatunku, aspekt intertekstualności.
\end{abstract}




\title{
intertekstualność
}

\section{SAMOŚWIADOMOŚć GATUNKU}

\author{
NOTA O AUTORZE: \\ Klaudia Pilarska - ur. w 1993 r. Absolwentka \\ Instytutu Filologii Wschodniosłowiańskiej UJ \\ na specjalności Kultura Rosji i Narodów Są- \\ siednich. Obecnie studentka II roku krytyki \\ literackiej UJ. Jej zainteresowania koncentru- \\ ją się na literaturze współczesnej, popkulturze \\ i językach obcych.
}

